\title{
School Inclusion and Classroom Management: Challenges and Possibilities
}

\author{
Relma Urel Carbone Carneiro', Maria Júlia C. Dall' Acqua ${ }^{2}$, Patricia Moralis Caramori ${ }^{3}$ \\ ${ }^{1}$ Department of Educational Psychology, Faculty of Science and Letters (Faculdade de Ciências e Letras), \\ Universidade Estadual Paulista (UNESP), Araraquara, Brazil \\ ${ }^{2}$ Postgraduate Program in School Education, Faculty of Science and Letters (Faculdade de Ciências e Letras), \\ Universidade Estadual Paulista (UNESP), Araraquara, Brazil \\ ${ }^{3}$ Doctor in School Education, Faculty of Science and Letters (Faculdade de Ciências e Letras), Universidade \\ Estadual Paulista (UNESP), Araraquara, Brazil \\ Email:relmaurel@bol.com.br, juliacandal@gmail.com,p.caramori@uol.com.br
}

Received 20 August 2015; accepted 16 November 2015; published 19 November 2015

Copyright () 2015 by authors and Scientific Research Publishing Inc.

This work is licensed under the Creative Commons Attribution International License (CC BY).

http://creativecommons.org/licenses/by/4.0/

(c) (i) Open Access

\section{Abstract}

This article is a part of a study conducted with regular classroom teachers and multifunctional resource rooms' teachers, who work with target-students of Special Education, which comprises, in Brazil, students with disability and global development disorders or high ability/gifted students. Through a participatory research with a cooperative counseling approach and using the focus group technique, we developed a study which objective was to investigate the teaching practices in inclusive classrooms and multifunctional resource rooms. For this article purposes, we will present data about classroom management aspects, presenting the challenges and possibilities emerging from one school inclusion experience. The participating teachers are from a medium-sized city of São Paulo state (Brazil), who works in the 1st cycle of the elementary school. There were discussion meetings with the teachers, which we recorded in video and audio with all the participants' agreement, followed by transcription and data analysis. Results show that the teachers' teaching behaviors are based in the concepts that guide them. There seems to be no doubt that teaching as a support to school inclusion should be the object of a critical analysis with the intention of generating a collective effort for a classroom management meant to facilitate the learning of all students, despite the fact of being identified as Special Education Students or not.

\section{Keywords}

\section{Classroom Management, Special Education, School Inclusion}




\section{Introduction}

The Brazilian educational scenario, as many others across the world, has discussed, during the last years, more precisely the last two decades, and in the form of policies and practices, changes concerning a shift in paradigm, in order to offer equal opportunities of access to high quality education to all the school population. We call this movement school inclusion, for its basic premise is that every student, regardless any characteristics or status, must be able to share the same spaces in their educational process. This movement is necessary because school has historically excluded certain groups considered ineligible for various reasons, like ethnicity, religion, social status, and others. Among these groups, we point out persons with disabilities, who-besides the difference resulting from their condition—have been represented as socially incapable and incompetent throughout time.

The school inclusion of students with disabilities, which fundamentals are contemplated in national and international documents—such as the Federal Constitution (Brazil, 1988), the World Declaration on Education for All (Declaration, 1990), the Law of Directives and Bases of National Education (Brazil, 1996), among many others-implies a change in concept, according to which all citizens shall be able to fully live their citizenship in collective learning environments. Such practice, though, which is quite recent, requires the search of a pedagogical acting that propitiates the development and learning of all students, considering their specificities.

The great diversity of students forming the classrooms in inclusive schools presents a number of challenges regarding these classrooms' management. According to Stainback \& Stainback (1999: p. 335), the class management is the key characteristic of an efficient teacher. An appropriate management contributes a great deal to every student's learning must be a part of each teacher's pedagogical planning, including preventive approaches, general intervention approaches, motivational approaches, and support and communication approaches. Other abilities required for teachers concerned about developing a good management of their classrooms involve:

- knowing research and theory regarding classroom management;

- knowing the students' needs;

- knowing how to establish positive relationships that help satisfy the basic psychological needs of students;

- knowing how to use teaching methods to promote the learning of students individually and of the whole group;

- knowing how to use teaching methods which maximize the students' behavior during the chores;

- knowing how to use a great variety of methods that involve students in examining and correcting their inappropriate behaviors (Stainback \& Stainback, 1999: p. 336).

The abilities described by the authors quoted present a list of characteristics that, for their nature, involve professional training. Teachers who are able to develop good management in classrooms formed by different students are not born ready. A primary training focused on this topic and a constant training at work, able to offer defined times and spaces for teachers to work with these aspects of their routine, is fundamental for the implementation of this practice.

Faced with students with challenging behaviors, it is necessary for the teacher to have a list of strategies in order to help him/her manage the classroom, so that he/she can develop a proper job, considering the challenging students' characteristics without prescinding his/her role and the objectives proposed for that classroom. According to Brazil (2002, p. 20), there are some hints that can be useful for the teacher and which refer to organizational adaptations that can help in the classroom. These are:

1) It is important for the teacher to clearly establish with the students which are the limits required to share a complex collective environment.

2) It is fundamental to identify the most suitable form of communication for each student, so that he/she can work with comprehension, pleasure and the greatest independence possible.

3) It is important that teaching is individualized, guided by a Teaching Plan that recognizes the student's special educational needs and reacts to them in a pedagogical manner.

4) It is important that students, whenever possible, are able to relate what they are learning at school to the situations they face in their own lives.

5) It is also important that academic activities take place in a meaningful and stable environment for the student.

6) The predictability of activities and events can lessen very much the anxiety of the student with non-adaptive behaviors. Therefore, it is important for the teacher to structure the use of time, space, material and the performance of activities, in order to reduce ultimately the chaos that a complex environment may represent for 
this student (Brazil, 2002: p. 20).

Because it is a relatively new educational model and because it implies difficulties, such as working with students who present unique characteristics, the regular teacher does not always feel apt to perform this role. In Brazil, the school inclusion policy for students with disability and global development disorders or high ability/ gifted students, which are the target-audience of Special Education (PAEE), provides for a special education service that is complementary to regular school and has the goal to offer support to these students' schooling. This service must be offered by a specialized teacher in multifunctional resources rooms during the period of time opposed to the student's attendance to the regular class. By this model, the specialized teacher's role, that he/she used to perform in an isolated and substitutive fashion, becomes complementary or supplementary, but always cooperating with the regular teacher. According to Carneiro (2012, p. 19):

It is certain that the regular teacher, not used to working with target-students from special education programs, needs specialized support for the implementation of adjustments to his/her pedagogical practice.

The specialized teacher's work, therefore, ceases to be performed exclusively with the student with special educational needs and becomes a partnership with the regular teacher, with whom he/she works in planning the adjustments required.

The cooperative work between the regular teacher and the specialized teacher should enable the planning of pedagogical actions in order to satisfy all the students' needs, including instructional and behavioral aspects. According to Valle (2014, p. 124): the lessons planning, meant to create an interactive and involving learning environment, must always comprise components like generating goals (instructional, social and behavioral); providing opportunities to demonstrate recent skills and findings; proposing compelling questions in order to learn about the students' previous knowledge; explicitly express what is expected of the students, providing opportunities to obtain clear explanations about content and multiple opportunities for the students to get involved in it; assuring that students understand the content proposed; providing opportunities for them to show their knowledge; and finishing the class revising what has been learned (information proposed) and what was understood (students' connections). The complexity of such planning shows the importance of the partnership between the regular and the specialized teachers in inclusive classrooms, where the students' diversity requires forms of organization and management capable of meeting each student's particularities.

A high quality, efficient teaching implies, among other aspects, an efficient classroom management and should be a concern of all those involved in the educational process.

\section{Method}

This study is characterized, in its general goal, as a Participatory Research with Cooperative Counseling approach, using the Focus Group as the technical procedure.

The research participants are teachers with professional training in special education working at the special education service (AEE) and regular teachers of the first cycle of elementary school-from the $1^{\text {st }}$ to the $5^{\text {th }}$ grade. For clarity purposes, we point out that elementary school, in Brazil, is divided in two cycles: the first one goes from the 1 st to the 5th grade and the second one goes from the 6th to the 9th grade. In cycle I, the students' ages range from 5.5 to 11 years. In cycle II, ages vary from 10.5 to 14 years.

There were discussion meetings with the teachers, which were video and audio registered with their agreement, followed by transcription and data analysis. The activities took place in the Municipal Secretariat of Education and in a school of a medium-sized city with circa 200 thousand inhabitants, located in São Paulo state.

In the first meeting, after the presentation of the project as research and intervention, as well as its goals, the participants signed the Informed Consent Form and the shooting authorization. Thereafter, they answered a questionnaire for the characterization of the teachers and the multifunctional resources rooms.

Data were collected during the meetings with the teachers, which took place in three different moments. The first one was based on trigger questions, focused on the expression of opinions regarding each thematic axes. In a second moment, the research team used a discussion to introduce the presentation of theoretical and legal aspects of the themes addressed. Finally, in the third moment, there were the confrontation and the raising of propositions about that theme. We called confrontation the moment which goal was to contribute to deepen the reflection, when all participants were able to review and analyze what they had declared before about the theme.

The trigger questions script had the goal to facilitate and trigger opinions by the participants. The intent was 
to start reflections and have the teachers think about their own professional practice. Cooperative counseling is represented by the researchers, who guide the discussions and participate in them, in order to collect important data that will lead to reflections about the pedagogical performance and to posterior changes in the teachers' routine.

According to Ibiapina (2008, p. 96), reflective sessions are a:

[...] procedure that motivates teachers to focus their attention on the teaching practice and teaching intent, as well as it encourages the creation of spaces for critical reflection that help develop the awareness of the teaching work, so that teachers develop their professionalism as they share problems, discuss and determine theoretical points of view, analyze the factors that condition their activity, and observe meanings and senses issued by their peers.

Regarding the questionnaires first applied to the specialized teachers, the data tabulation showed that the participants' age group ranged from 28 to 50 years, with medium age from 38 to 47 . All the 22 participants were women and worked in the urban area. Half of them were graduated in Teaching at high school level (the course was called Magistério then), all of them had a university degree, 21 had a license in intellectual disability, one in multiple disabilities and 11 were specialized in different areas.

The experience as a special education teacher varied from two to 31 years. Regarding the teaching level they were working at, seven teachers worked in the childhood education, 12 in the elementary school, one assisted a high school student and 12 special education students (some teachers worked in two different levels). The working places included Education and Recreation Centers (Centros de Educação e Recreação-CER), Municipal Elementary Schools (Escolas Municipais de Ensino Fundamental-EMEF), Special Education Service Center (Centro de Atendimento Educacional Especializado-CAEE) and Special Institutions (Instituições Especiais).

The students enrolled were identified with intellectual, auditive, physical, visual and multiple disabilities, global development disorders and autism. The service mode varied from individual and in pairs to small groups, and teachers assisted 11 students per week at the period of data capture.

The two regular teachers were both women and had an average age of 30 years. Both worked in the municipal rural area and had a university degree in Pedagogy. Only one of them had more experience time in the municipal education network; for that reason, they had already participated in continuing training courses offered by the Municipal Secretariat of Education. One of the teachers had nine years of experience in working with regular teaching in the State Education Network and the other one was a recent university graduate, without experience in places other than the municipal network.

We present the results from the analysis of the participants' speech regarding the classroom management below. It is worth highlighting that the speeches highlighted do not identify the teachers individually; they only illustrate the analysis performed. That is because our goal was not to characterize each one of the participants, but to build a narrative that would allow us to understand the context of the focus groups meetings and the understanding of the teachers about the questions discussed instead.

\section{Results and Discussion}

The participant teachers' speech facilitated the production of both specific and comprehensive themes, characterizing situations in which the context of inclusive education of a school from a Brazilian city showed to be fundamental to enable the detection of some important hints on classroom management through the actions of regular and specialized teachers, as we will try to present.

In order to confirm that a student enrolled in a regular class is also followed by specialized teachers in the school counter-round, a technical team composed by a psychologist, a speech therapist, a pedagogue and a psycho pedagogue perform screening and assessment is formed. Their goal is to determine if there were any discrepancies compared to the curriculum developed at school and if the student presents any delays. Since the proposal that guides the service offered to these students requires that they attend regular classes, participating in the Multifunctional Resources Rooms (SRMs) program in the opposite period, specialized and regular teachers report some points that they consider facilitators or obstacles to the classroom management.

They will be presented in two lines of analysis. The first phase refers to themes considered structural, aligned to the legislation in force and that, being so, have the guideline to keep the student in the regular class, but, in the counter-round, take him to the special education service (AEE). The second part, on the other hand, is cha- 
racterized by functional conditions, namely the way teachers organize their practice.

The data collected show that, while the guidelines of Special Education from the Perspective of Inclusive Education Program (Brazil, 2008) establishes that the multifunctional resources rooms (SRMs) must be destined to every student considered Target-Audience of Special Education (PAEE), special classrooms destined to students with both physical and auditive disabilities were organized in the city of the study. For practical reasons like, for example, allocating all the physical, material and human resources in the same space, the decision was to proceed that way. Faced with the need of a more effective assistance for some students to use the bathroom, for changing diapers, for example, organizing a single space that could concentrate most service for such needs was considered more viable. For the purpose of classroom management, the initiative was supported by most of the teachers, who advocate that, in order to be more effective, the teaching work must be category-based, not only in terms of physical changes to the school space, but also because they feel unprepared to work within a multiplicity of conditions. The teachers who are responsible for the special education service point out the difficulties to deal with all categories of students, regardless their initial, continuing or in-service training. The following speeches are representative and describe the teachers' reasons.

For example, I am not apt to teach a student with visual or auditive disabilities. I would have to learn a lot, I really do not know how to do it; I would have all my good will, but I do not really have the knowledge... Before this student's arrival, yes, we would have to be more prepared...

When I was teaching in a special classroom, most students were children with Down syndrome; I tried to catch up, studied, looked, and observed. Now we have new disabilities, autism is hard, because there are so many kinds, so you have to try to catch up, so I do not feel apt to work with all those disabilities.

... We cannot know everything all the time.

We take a little bit of each one, because there are auditive and visual disabilities, autism, many disabilities are covered. I always say that it should be only one disability, to work with a single disability.

While this is a repetitive complaint of the specialized teachers, for the regular teachers the difficulty is to organize the lessons in order to meet all the demands when there is an inclusive student in the classroom. These teachers also report unpreparedness and the challenge of the diversity that the inclusive education brings.

My greatest difficulty is working with all the students at the same time. Because there are 19 students, the classroom is not as large as it could be in other schools, where I would have much more difficulty, but you have to give attention to all the students anyway, it is very complicated. Because I cannot leave the class aside to work individually with one student and I cannot leave him aside to work with the class either, cause he will not follow.

Because when I work with the same activity the rest of the class is performing, this student cannot follow and I think it is not very useful.

In face of the difficulties reported both by regular and specialized teachers, it becomes possible to understand that, although inclusion is a reality, since a growing number of PAEE students has been registered in regular schools (Castro, 2015), the teaching work aimed at inclusive contexts, in turn, has been an object of concern (Caramori, 2014; Otalara, 2014). That is because the teacher's practice, the classroom performance, namely the so-called teaching activities, have showed to be significantly fragile and, at the same time, provocative, as explained by Mendes, Vilaronga and Zerbato (2014).

An additional difficulty found in our context is the fact that the resources room has become "multicategorial" in the last years, that is, a center for children with various disabilities, without any special attention for the labels. [...] This model, though, creates insurmountable obstacles to the teachers' training, for they are obliged to master knowledge and teaching abilities of different groups of Special Education (Mendes, Vilaronga, \& Zerbato, 2014, pp. 24-25).

Analyzing this aspect from the classroom management perspective, the teachers participating in this study evince, through their speech, the great challenge that is presented in the face of this demand. A new way to organize the work, which has been faced in an intuitive manner, by trying, seeking to make it right and learning with the experience is being built.

Now, more than ever, I am doing this because it is something I have seen that really works, that flows in 
my classroom.

The first year is a critical phase, with many writing mistakes, lack of letters, things like that. So I try to write it down on the board and ask who did it the same way, if there is something someone forgot. If you forgot it, it is wrong, but all you have to do is take your friend eraser and correct it. I recover the letter, the sound. I must do it all the time.

Then, there is the fact of organizing the students in pairs, they help each other, or even orally, when someone asks a question, I ask the classroom to answer it. I saw that this really works and it helps a lot, also because they all speak the same language, I guess. Sometimes I explain in a way I can see that does not flow, that the student does not understand, then his mate explains it and he gets it. I think this is very important.

Going to schools where students are enrolled in regular classes, the teachers of AEE are prompt to work in a complementary way to the regular teachers who, in their turn, are faced with the need to rethink their practice within a collaborative model. In that sense, it is important to inquire about the classroom didactic organization in order to provide the engagement of two teachers, both responsible for the student, but each one having his/her own characteristic, which certainly requires changes to the classroom management. Traditional, dichotomous practices do not seem to cope with the teaching performance that is necessary. Maybe this is the core point about the changes the inclusion paradigm requires, as well analyzed by Carneiro (2011):

The teacher of the school that is part of the inclusion paradigm is responsible for the reorganization of his/her own identity, reoccupying his prominently pedagogical role of teaching responsibility and learning by all the students. According to the teachers' speech, the practice of this principle is very complex, since they declare to be unprepared for this task. This preparation shall occur in the beginning of the new teachers' professional training, in constant in-service training as an essential element for the reflection about the teaching performance, but, fundamentally, and with the risk of disabling the previous actions, in the form of a practical exercise of the teaching performance with the student with disability and his peers, starting from the belief and the recognition of his/her ability to learn (Carneiro, 2011: p. 49).

However, according to the teachers’ perception, both regular and specialized, cooperative teaching exposes this transformation with more vigor. Moreover, it requires the reorganization of the teaching performance.

I will try to tell. I think many things have changed in our practice, we came to work with students in smaller groups, they go to the resources room once or twice a week, we guide the teachers, which is a great challenge for us, we do individual planning, AEE planning, curriculum access planning. So I think the partnerships increased, we have partnerships with speech therapists, psychologists... First, we did not, it was all limited to the classroom, it was the teacher and the student, the student and us and that was all. Nowadays it is different; our engagement with the student has increased.

The work dynamics has changed, we do not work alone anymore, you have the need to search new findings, you have to look for the other person's needs, you do it, you depend on the other person, and you have the speech therapist, the articulate teacher, the student, the family. So, first you used to work only with the student the whole year, the whole week, not now.

We feel the difference... You are responsible for the teachers who work with your students and also for the team that works your students.

However, this model of partnership and cooperation, also called “co-teaching” (Beyer, 2005), or bidocência in Portuguese, pointed out as promising by the literature, and which implies changes in the whole school system, denotes, in practice, the need of more reflection about roles and functions.

It is important to work on inclusion, because otherwise you do not know how to guide the teacher through the inclusion in the regular class...

(...) Actually, we are not working the same things as the teacher. We work with difficulty, strategy...

One great challenge of being integrated is working with the teacher in the classroom, with the teachers; the student has more than one teacher, so the great challenge is have this work done.

And I think we have a great partnership with health-care providers, it has increased a lot, I think our role has increased a lot in a large scale. From my point of view, it has totally changed our way of working.

The perception that the responsibility for guiding the regular classroom teachers, among others, belongs to the 
special education, contrasts with the change in approach, for...

(...) if teaching in the regular classroom does not fit this student's needs and poorly favors his/her participation and learning, it will be useless for his/her to expand his/her learning hours in one or two weekly hours in order to offer AEE, as if the problem was focused on the student with disability and not on the school (Mendes, Vilaronga, \& Zerbato, 2014: p. 26).

Considering that the teachers' teaching behaviors are built upon the concepts that guide them, there seems to be no doubt that teaching, as a support to school inclusion, needs to be the object of a critical analysis with the intention of generating a collective effort for classroom management meant to facilitate the learning of all students, despite the fact of being identified as students with disabilities, global development disorders or high ability/gifted students or not. The Curriculum Access Plan, designed and performed in a collaborative way, certainly shows the need of a redefinition of the teachers' roles in a more collective action sense. As pointed out by Mendes, Vilaronga and Zerbato:

(...) collective work requires collective sharing, in which no one will find him/herself in the position of a mere apprentice of new practices and strategies, but as professionals united to share knowledge and practices searching for a common goal, which is the successful schooling of all students (Mendes, Vilaronga, \& Zerbato, 2014: p. 43).

\section{Final Comments}

The reflections presented here meant to highlight some aspects that were identified in the teachers' speech about issues involving the classroom management, in order to shed some light on structural and functional conjunctures and its consequences.

School can no longer remain an exclusion space characterized by homogeneity. In that sense, the challenge becomes to overcome this condition, aiming at assuring high quality teaching and the same opportunities to everyone. This is the great challenge of the new school that needs to be built.

In the meeting space for regular and specialized teachers, the mutual development and learning impose the need of new forms of work.

Since the teachers declare themselves unprepared for the pedagogical work with such diverse students, it is an important task to develop the collaboration that promotes mutual engagement. Learning how to work together requires a change in position, from individual to collaborative. Classroom management moves from the solo teacher to partner teachers who embrace the task to make decisions together and who both feel responsible for the students with disabilities, global development disorders or high ability/gifted students.

With a student-centered pedagogy, based on cooperation, nor the teacher or the students might work alone. Small groups and teams whose members are willing to help each other are fundamental. They allow the teacher to have more time to focus on the students with more needs. In this form of organization, diversity challenges the teachers but can also become their greatest ally. "Therefore, the organization of activities in collaboration leads students to count on each other, cooperate and help each other throughout the development of the activity” (Maset, 2011: p. 52).

From this perspective, the specialized teachers' speech about feeling undermined when they are not able to fully guide their colleagues of the regular classrooms loses its sense. They are not responsible for guiding, but for helping to rethink the organization of the pedagogical work. The Curriculum Access Plan puts shared performance in the center of decisions. It is necessary to establish a plan to move on.

Therefore, if on the one hand the structural conditions define the changes needed in order for the functional conditions to change too, on the other hand, policies will be achieved only when the classroom work also changes.

Much more than looking outside and wishing that a teacher of notorious knowledge will come to give the answers to so many questions. The classroom management in inclusive schools implies redirecting the vector to the core of the teaching practices and performances.

\section{References}

Beyer, H. O. (2005). Inclusão e Avaliaçãona Escola de Alunos com Necessidades Educacionais Especiais (School Inclusion and Evaluation of Students with Special Education Needs). Porto Alegre: Editora Mediação. 
Brazil (1996). Law Number 9.394, December 20, 1996. Defines the Directives and Bases of National Education. Diário Oficial da União. Brasília. Dec. 23, 27.833-27.841.

Brazil (2002). Secretariat of Special Education (Secretaria de Educação Especial) Projeto Escola Viva (Live School Project)— Assuring Access and Permanence of All Students at School—Students with Special Educational Needs (Garantindo o acesso e permanência de todososalunosnaescola_-Alunos com necessidadeseducacionaisespeciais). 2nd Series. Brasília.

Brazil (2008). Special Education from the Perspective of Inclusive Education (Política Nacional de Educação Especial na Perspectiva da Educação Inclusiva). Inclusion: Revista da Educação Especial, Brasília: CIBEC/MEC, v.4, n. 1.

Brazil. Federal Constitution (1988). Constituição da República Federativa do Brasil (10th ed.). Brasília, DF: Senate.

Caramori, P. M. (2014). Estratégias Pedagógicas e Inclusão Escolar: Um estudosobre a educaçãocontinuadaemserviço de professores a partir do trabalhocolaborativo (Pedagogical Strategies and School Inclusion: A Study on In-Service Continuing Training for Teachers from a Collaborative Work). Thesis (Doctorate in School Education), Araraquara: Faculty of Science and Letters (Faculdade de Ciências e Letras)—São Paulo State University (Universidade Estadual PaulistaUNESP).

Carneiro, R. U. C. (2011). Identidade e Representaçõesna Escola Inclusiva (Identity and Representations in the Inclusive School). In: S. A. I. Monteiro, R. Ribeiro, S. de S. Lemes, \& S. R. Muzetti (Eds.), Educaçõesna Contemporaneidade (Education in Contemporaneity): Reflexões e Pesquisa. São Carlos: Pedro e João Editores.

Carneiro, R. U. C. (2012). Formação de Professores: Da Educação Especial à inclusiva-Alguns Apontamentos (Teachers’ Training: From Special to Inclusive Education—Some Notes). In: L. O. Zaniolo, \& M. J. C. Dall'acqua (Eds.,) Inclusão Escolar: Pesquisando Políticas Públicas, Formação de Professores e Práticas Pedagógicas (School Inclusion: Researching Public Policies, Teachers’ Training and Pedagogical Practices). Jundiaí: Paco Editorial.

Castro, V. D. B. de (2015). Inclusão Escolar no Período de 2009 a 2013 sob a Perspectiva das Matrículas no Censo Escolar (School Inclusion in the Period from 2009 to 2013 from the Perspective of Enrollments in the School Census). Dissertation (Master in School Education), Araraquara: Faculty of Science and Letters (Faculdade de Ciências e Letras)—São Paulo State University (Universidade Estadual Paulista_UNESP).

Declaration (1990) World Declaration Education for All, Jomtien-Tailândia. World Conference on Education for All: Satisfying the Basic Learning Needs, Jomtien-Tailândia, 5-9 March 1990.

http://www.unicef.org/brazil/pt/resources_10230.htm

Ibiapina, I. M. L. de M. (2008). Pesquisa Colaborativa: Investigação, Formação e Produção de Conhecimentos (Collaborative Research: Investigation, Training and Knowledge Production). Brasília: Liber Livros Editora.

Maset, P. P. (2011). Aulas Inclusivas e Aprendizagem Cooperativa (Inclusive Lessons and Cooperative Learning). In: D. Rodrigues (Org.), Educação Inclusiva: Dos Conceitosàs Práticas de Formação (Inclusive Education: From Concept to Training Practice) (pp. 45-88). Lisboa: Piaget Institute.

Mendes, E. G., Vilaronga, C. A. R., \& Zerbato, A. P. (2014). Ensino Colaborativo como Apoio à Inclusão Escolar: Unindo Esforços entre Educação Comum e Especial (Collaborative Teaching as Support to School Inclusion: Joining Forces between Regular and Special Education). São Carlos: Edufscar.

Otalara, A. P. (2014). A Formação de Professores para o Trabalho com DeficientesVisuais: Uma Experiência Inicial de Colaboração a partir do Desenvolvimento de Materiais Didáticos (Teachers' Training for Working with Visual Disability: An Initial Experience of Collaboration from the Development of Didactic Material). Thesis (Doctorate in Scholar Education), Araraquara: Faculty of Science and Letters (Faculdade de Ciências e Letras)—São Paulo State University (Universidade Estadual Paulista-UNESP).

Stainback, S, \& Stainback, W. (1999). Inclusão: Um Guia para Educadores (Inclusion: A Guide for Educators). Porto Alegre: Artmed Publisher.

Valle, J. W., \& Connor, D. J. (2014). Ressignificando a Deficiência: Da Abordagem Social às Práticas Inclusivasna Escola (Giving Disability a New Meaning: From the Social Approach to the Inclusive Practice at School). Porto Alegre: AMGH. 